\title{
Det passiva motståndets praktiker
}

\author{
Brutus Lagercrantz (1857-1929) och konflikten kring \\ likställighetslagen 1912
}

I OKTOBER I9I2 RAPPORTERADE finländsk press att distriktsdomstolen i S:t Petersburg hade dömt tre ledamöter av Viborgs magistrat till "fängelse för laglydnad". ${ }^{1}$ Den paradoxala rubriken - i en rättsstat döms man inte till fängelse för att man följer lagen, utan för att man bryter mot den - bör förstås i ljuset av den finsk-ryska rättskamp som präglade de sista årtiondena av storfurstendömets tid. I detta fall hade kampen resulterat $i$ att tre finländska tjänstemän hade ställts inför ett dilemma som tvingade dem att fatta ett beslut som de visste kunde resultera i fängelsestraff. I domslutet konstaterades att de åtalade, borgmästaren Werner Fagerström, rådmannen Georg Palmroth och t.f. rådmannen Brutus Lagercrantz, hade gjort sig skyldiga till att "uppenbarligen och afsiktligen ha hindrat tillämpningen av likställighetslagen". ${ }^{2}$

De tre ledamöterna av Viborgs magistrat var de första finländare som åtalades i rysk domstol för brott mot den likställighetslag som hade stiftats av ryska ministerrådet och duman I9II, stadfästs av Rysslands kejsare Nikolaj II i maj I9I2 och trätt i kraft i maj samma år. Lagen gav samtliga ryska undersåtar samma rättigheter i storfurstendömet Finland som personer med finsk medborgarrätt, och var stiftad i enlighet med ı9ıo års förordning om rikslagstiftning. Den stod i strid med finländsk rättsuppfattning och väckte protester redan när den förbereddes.

I. "Rättegången mot medlemmarna av Viborgs magistrat", Borgåbladet 26/ıo I9I2, s. 2.

2. Domslut (avskrift), Rättegången mot tjänstemännen i Viborgs magistrat (I9I2-I9I3), 8, Leo Mechelins arkiv, Riksarkivet, Helsingfors. 
I den här artikeln studerar jag Brutus Lagercrantz som passiv motståndsman i konflikten kring likställighetslagen rgı2. När Lagercrantz i oktober det året blev dömd för brott mot lagen hade han i 34 år innehaft olika tjänster inom landsstaten i Viborgs län. Född I857 hade han 2I år gammal inlett sin karriär som landskontorist vid länsstyrelsen 1878 , åren I882-I892 var han länsman i Taipalsaari och Sakkola och därefter fram till 1906 lanträntmästare vid länsstyrelsen. Från 1906 var Lagercrantz kronofogde i Stranda härad, som bland annat omfattade Viborgs landskommun, men från denna tjänst avskedades han i början av I9I2 efter en konflikt med guvernören i Viborgs län Frans von Pfaler. Efter avskedandet grundade Lagercrantz en privat advokatbyrå och verkade samtidigt som t.f. rådman i Viborgs magistrat. Det var i denna position som han hamnade i skottlinjen när likställighetslagen för första gången prövades sommaren I9I2.

I artikeln redogör jag inledningsvis för den politiska konflikten kring likställighetslagen och för bakgrunden till att de tre ledamöterna av Viborgs magistrat åtalades för brott mot den. I de följande avsnitten analyserar jag hur det passiva motståndet framträdde under rättskampen. Jag studerar hur Lagercrantz i praktiken tillämpade passivt motstånd, hur motståndet mot de ryska övergreppen tog sig uttryck i det omgivande samhället och hur pressen skildrade händelseförloppet. Jag intresserar mig därtill för hur eftervärlden framställde Lagercrantz och hans roll i konflikten. Källorna består i huvudsak av pressmaterial i Finlands nationalbiblioteks digitala tidningsarkiv. Särskilt den konstitutionellt sinnade pressen är relevant i sammanhanget eftersom den inte enbart skildrade konflikten utan även i sig var ett viktigt verktyg för det finländska passiva motståndet. Som komplement till tidningarna använder jag dokument som berör händelserna i Viborg I9I2 i Leo Mechelins arkiv och generalguvernörskansliets arkiv på Riksarkivet i Helsingfors.

Likställighetslagen väckte livlig debatt i samtiden, men har inte rönt särskilt stor uppmärksamhet i tidigare historieforskning. Matti Klinge förklarar det bristande intresset med att lagens betydelse var principiell snarare än praktisk. På grund av första världskrigets utbrott, som ledde till revolution i Ryssland och till att Finland blev självständigt I9I7, hann lagen få praktisk betydelse endast i Viborgs 
län som geografiskt låg närmast Ryssland. ${ }^{3}$ En studie av konflikten bidrar ändå med kunskap om hur en enskild tjänsteman tillämpade det passiva motståndets principer. Därtill belyser den de sätt på vilka det omgivande samhället kunde uttrycka sitt stöd för Lagercrantz, pressens centrala betydelse som ett verktyg i det passiva motståndet och hur minnet av konflikten efter I9I7 anpassades till Finlands förändrade geopolitiska situation.

Konflikten i Viborg I9I2-I9I3 har mest detaljerat skildrats på finska i Kaarlo Nuorvalas populärhistoriska verk Krestyn miehet från 1939. Den refereras även i början av Edvin Wiréns bok Från S:t Petersburgs fängelser från I9I7, som dock i huvudsak behandlar fängelseförhållandena för de finländska tjänstemän som åren I9I2-I9I7 satt fängslade i den ryska huvudstaden. ${ }^{4}$ Därtill har fallet väckt intresse bland rättshistoriker, då särskilt på grund av den roll Viborgs hovrätt spelade i konflikten. ${ }^{5}$ Händelserna har även behandlats ur pressens perspektiv i Erkki Paavolainens historik över tidningen Karjala, som var ett språkrör för det passiva motståndet. ${ }^{6}$ Anu Koskivirta placerar in konflikten i ett bredare politiskt sammanhang i artikeln "Venäläistäminen, viranomaisiin kohdistuneet puhdistukset ja vastarinta Viipurissa toisen sortokauden alkuvaiheessa n. I908-I9I3”. Hon behandlar åtalet mot Viborgs magistrat och Lagercrantz som ett av flera inslag i den rysk-finska kampen om Viborg i slutet av storfurstendömets tid. I samma antologi har jag själv skrivit en faktaruta om Lagercrantz i det historiska minnet. ${ }^{7}$

3. Matti Klinge, Kejsartiden. Finlands historia 3, Helsingfors: Schildts 2004, s. 464.

4. Kalervo Nuorvala, Krestyn miehet. Kuvaus yhdenvertaisuuslain aiheuttamasta oikeustaistelusta, Helsinki: Kustannusosakeyhtiö Sanatar 1939, s. I2I-I92; Edvin Wirén, Från S:t Petersburgs fängelser, Helsingfors: Holger Schildts förlag 1917, s. 15-23.

5. Jukka Kekkonen, Wiipurin Itä-Suomen hovioikeus I839-1989, [Kuopio]: Kustannuskiila I992; Wäinö Kannel (toim.), Viipurin hovioikeus I839-1939: tietoja hovioikeuden historiasta, toiminnasta ja virkakunnasta, Viipuri: Viipurin hovioikeus 1939, s. 7I-87.

6. Erkki Paavolainen, Sanomalehti Karjalan kobtaloita 1904-1954, Lahti: Karjalan Kirjapaino I954, s. I75-182 (magistraten), I83-187 (hovrätten).

7. Anu Koskivirta, "Venäläistäminen, viranomaisiin kohdistuneet puhdistukset ja vastarinta Viipurissa toisen sortokauden alkuvaiheessa n. I908-I9r3", Anu Koskivirta \&Aleksi Mainio (toim.), Politiikan ja jännitteiden Viipuri I880-1939, VSKS:n Toimitteita 2I, Helsinki: Viipurin Suomalainen Kirjallisuusseura 2019, s. I42-203; Johanna Wassholm, "Brutus Lagercrantz (1857-1929) - sankariksi kohotettu virkamies”, Anu Koskivirta \& Aleksi Mainio (toim.), Politiikan ja jännitteiden Viipuri I880-I939, VSKS:n Toimitteita 2I, Helsinki: Viipurin Suomalainen Kirjallisuusseura 20I9, s. 204-205. 
Det dilemma som Brutus Lagercrantz och de två andra ledamöterna av Viborgs magistrat ställdes inför sommaren I9ı2 hade sin bakgrund i den likriktningspolitik som den ryska centralmakten sedan sent I80otal hade tillämpat med syfte att försvaga eller helt eliminera Finlands autonomi. Den första aktiva fasen i denna politik inföll under Nikolaj Bobrikovs tid som generalguvernör I899-I905, en tid som ur finländskt perspektiv har kallats "ofärdsåren" eller "första förryskningsperioden". Efter det rysk-japanska kriget och 1905 års revolution lättade det ryska greppet om Finland för några år, för att åter stramas åt från I909 då Frans Albert Seyn (I862-I918) utnämndes till Finlands generalguvernör. Seyn hade varit chef för generalguvernörskansliet under Bobrikovs tid och återupptog det konsekventa förryskningprogram som då inletts. Åtgärderna ledde till att Edvard Hjelts parlamentariskt valda senat avgick och ersattes av en tjänstemannasenat. Den nya senatens medlemmar var i huvudsak finländska officerare som hade tjänstgjort i Ryssland eller ryssar med medborgarrätt i Finland, och senaten kallades därför i folkmun för "amiralssenaten" eller "sabelsenaten". Senatorerna hade svaga personliga kontakter till Finland och var beredda att stödja förryskningsprogrammet. ${ }^{8}$

I juni ıوIo återinfördes den så kallade rikslagstiftningen, som varit i kraft I899-I905 och som innebar att lagar som hade rikspolitisk betydelse skulle stiftas av ryska duman. Finlands lantdag ombads ge ett utlåtande i frågan, men vägrade med hänvisning till att lagen skulle tillkomma på icke-konstitutionell väg. Med samma motivering vägrade lantdagen att utse de två ryskkunniga finländska ledamöter som enligt den nya lagstiftningsordningen skulle ingå i riksduman, likaså de två ledamöter som skulle ingå i rikskonseljen. På grund av andra konflikter upplöstes lantdagen, och då senaten redan var i de rysksinnades händer var storfurstendömets politiska system på central nivå i praktiken satt ur spel. ${ }^{9}$

8. Klinge, Kejsartiden, s. $456-457$.

9. Uuno Tuominen, "Rikslagstiftningen", Päiviö Tommila (red.), Finlands ofärdsår I899-I9I7, Stockholm: Wahlström \& Widstrand I963, s. I70-I72. Gällande t.ex. armén, mynt, utrikeshandel och post- och tullväsende var lagstiftningen redan gemensam. 
Lagen om rikslagstiftningen stadgade att ryska riksduman skulle stifta lagar som berörde Finlands andel i rikets utgifter, värnplikten, ryska språkets ställning, tryckfrihetsfrågor, tull-, post- och järnvägsfrågor, myntsystemet, handels- och industrifrågor samt i Finland bosatta ryska undersåtars rättigheter. ${ }^{10}$ Likställighetslagen (fi. ybdenvertaisuuslaki; ry. zakon o ravnopravii) knöt an till den sistnämnda frågan, som bottnade i en gammal konflikt. I början av r9oo-talet hade man från rysk sida anklagat finländarna för att med bedrägliga medel ha tillskansat sig privilegier som gav dem själva samma rättigheter som infödda ryssar i hela ryska riket - bland annat rätten till fri näringsutövning och inskrivning i lokala samfund - samtidigt som de förvägrade i storfurstendömet bosatta ryssar motsvarande rättigheter. Där finländarna samtidigt var både finska medborgare och ryska undersåtar, behandlades ryska undersåtar i Finland i många avseenden som utlänningar. ${ }^{11}$

Likställighetslagen utplånade i stort sett den juridiska skillnaden mellan finska medborgare och ryska undersåtar i storfurstendömet; endast de politiska rättigheterna, det vill säga rätten att delta i lantdags- och kommunalval, förbehölls fortsatt finska medborgare. ${ }^{12} \mathrm{De}$ mest betydande följderna av lagen var att personer utan finsk medborgarrätt kunde inneha offentlig tjänst i Finland, och att samtliga ryska undersåtar hade rätt att idka näring på samma villkor som finska medborgare. ${ }^{13}$ Lagen handlade ur rysk synvinkel om jämlikhet mellan samtliga ryska undersåtar, medan den ur finsk synvinkel sågs som ett allvarligt hot mot storfurstendömets autonomi, rentav en rysk "maktusurpation". ${ }^{14}$

Särskilt starkt i strid med finsk rättsuppfattning stod den paragraf i lagen som stadgade att finländska tjänstemän som bröt mot den skulle

Io. Klinge, Kejsartiden, s. $456-457$.

II. Max Engman, "Borgare och skenborgare i Finland och Ryssland under första hälften av I800-talet", Historisk Tidskrift för Finland 63, 1978:2, s. 189. Finländarna behandlades i Ryssland som ett "stånd", en kategori av ryska undersåtar med en särskild juridisk status, och hade i praktiken i vissa avseenden bättre villkor än ryssar.

I2. Engman,"Borgare och skenborgare", s. I89.

I3. Koskivirta, "Venäläistäminen", s. I69. Frågan om ryska undersåtars näringsrätt i Finland hade varit ett tvistefrö redan 1899-1905.

I4. "Viborgs magistrat och 'likställighetslagen"', Wiborgs Nyheter 2/8 I9I2, s. 2. 
åtalas i rysk domstol. Detta var ett försök från rysk sida att förhindra att finländska tjänstemän gjorde passivt motstånd för att motarbeta lagens tillämpning, så som en del gjort 1899-1905. Den ryska regimen vidtog också andra åtgärder för att försvåra framtida motstånd. Redan innan lagen trädde i kraft hade många centrala administrativa poster på regional nivå besatts med personer som stödde likriktningspolitiken. I Viborgs län hade guvernör Birger von Troil ıgır ersatts av Frans von Pfaler, som tidigare hade gjort karriär i Ryssland, senast i Turkmenistan i Centralasien. Därtill hade Viborgs polismästare Alfred Lucander avskedats och ersatts av Vilho Pekonen. Den ökände Pekonen hade varit kommissarie i Helsingfors i början av I900-talet, och I905 dömts till fängelsestraff bland annat för förfalskning av räkningar, förskingring av offentliga medel och olaga arrestering. Därefter hade han för att undkomma fängelse flytt till S:t Petersburg. Bestörtningen var stor i Finland när den ryska regimen senare friade den impopuläre Pekonen och i februari I9II utnämnde honom till polismästare i Viborg. ${ }^{15}$

När likställighetslagen trädde i kraft i maj ıوı2 var man i Finland väl medveten om att det var en tidsfråga innan den skulle prövas, och även om att de tjänstemän som då råkade befinna sig i skottlinjen skulle hamna i en besvärlig position. Den I juli ı9ı2 anmälde en rysk undersåte från guvernementet Jaroslavl, Ivan Michailovitj Sopetov, skriftligt till magistraten i Viborg att han ämnade idka handel med kött och vilt i staden. Magistratens ledamöter stod nu inför ett dilemma; om de beviljade Sopetov näringstillstånd bröt de mot den finska lag som de i sin tjänsteed hade svurit att följa. Om de däremot vägrade ta emot anmälan, bröt de mot den ryska likställighetslagen och riskerade att bli åtalade för tjänstebrott i rysk domstol. Väl medveten om de potentiella följderna beslöt magistraten på sitt sammanträde den 3 juli att inte bevilja Sopetov näringstillstånd. ${ }^{16}$

I5. Koskivirta,"Venäläistäminen", s. I49-I6r. Polisstyrkan i Viborg hade också utökats kraftigt.

I6. Pressen rapporterade första gången om fallet i början av augusti. Se t.ex. "Den ryska likställighetslagen tillämpas", Nya Pressen I/8 I9I2, s. I; "Likställighetslagens tillämpning", Wiborgs Nyheter I/8 I9I2, s. 2; "'Yhdenwertaisuuslain' sowelluttaminen", Helsingin Sanomat 2/8 I9I2, s. 2-3. Sopetovs namn förekommer i källorna med varierande stavning, t.ex. Sobedoff, Sopetoff, Sapetoff och Sobetow. 
Sopetov överklagade magistratens beslut hos guvernör von Pfaler, som i en skrivelse den 20 juli påminde magistraten om att likställighetslagen förpliktade den att ta emot ryska undersåtars näringsanmälan. Han krävde att magistraten inom tio dagar skulle lämna in en redogörelse över sitt förfarande, inklusive namnen på de ledamöter som hade tagit del $\mathrm{i}$ ärendets behandling. I sitt svar motiverade magistraten sitt nekande beslut med att Sopetov saknade medborgarrätt i storfurstendömet Finland, och att han därför i enlighet med paragraf I2 i 1879 års finska näringsförordning borde anhålla om näringstillstånd hos länets guvernör. Av svaret framgick också att borgmästare Werner Fagerström varit ordförande för sammanträdet, medan Georg Palmroth och "adjungerade förre kronofogden i Stranda härad" Brutus Lagercrantz deltagit som ledamöter. ${ }^{17}$

Magistratens svar tillfredsställde inte von Pfaler, som anklagade ledamöterna för brott mot likställighetslagen. Efter en livlig skriftväxling mellan magistraten, von Pfaler och generalguvernör Seyn, anmälde den sistnämnda fallet till prokuratorn vid appellationsdomstolen i S:t Petersburg. ${ }^{18} \mathrm{I}$ den finländska pressen inleddes så snart fallet blivit känt spekulationerna om vad som skulle hända härnäst. Man påminde om att avsiktligt motarbetande av likställighetslagens tillämpning skulle leda till åtal i rysk domstol och kunde bestraffas med böter eller fängelse upp till $\mathrm{I}$ år och 4 månader. Den åtalade kunde även suspenderas från sin tjänst eller dömas till förlust av medborgerliga rättigheter för upp till Io år. ${ }^{19}$ En insändarskribent i Dagens Tidning konstaterade att varje fosterlandsvän nu med "blödande hjärta" tvingades bevittna hur en växande lavin sattes i rullning. Lavinen skulle sannolikt leda till att "[m]ånga behjärtade män skola kastas kull och ryckas bort". ${ }^{20}$

I7. "Den ryska likställighetslagen tillämpas", Nya Pressen I/8 I9ı2, s. I."Hans Kejserliga Majestäts Nådiga Förordning om näringarne”, paragraf I2, Finlands Författningssamling I2:I879.

I8. Pirkko Leino-Kaukiainen \& Jukka Partanen, "Tiellä venäläiseen Suomeen”, Yrjö Kaukiainen, Risto Marjomaa \& Jouko Nurmiainen (toim.), Autonomisen Suomen rajamaa. Viipurin läänin historia V, Joensuu: [Karjalan kirjapaino] 2014, s. 504.

19. "Likställighetslagens tillämpning", Hufvudstadsbladet 20/8 I912, s. 4.

20. "Tillämpad olag", Dagens Tidning 2/8 I9ı2, s. 3 . 
I mitten av augusti återgav finländsk press notiser i ryska tidningar som hävdade att Viborgs magistrat skulle åtalas i Ryssland. ${ }^{21} \mathrm{Ap}^{-}$ pellationsdomstolen hade överlämnat fallet till distriktsdomstolen i S:t Petersburg och den 22 augusti anlände två ryska domare - rannsakningsdomaren V.N. Sereda och prokuratorsadjointen V. Popov - till Viborg för att göra en förundersökning. De fick ett arbetsrum i länsstyrelsens hus där förundersökningens viktigaste del, förhör med Lagercrantz, Palmroth och Fagerström, skulle äga rum. ${ }^{22}$

\section{DET PASSIVA MOTSTÅNDETS PRAKTIKER}

Magistratens vägran att ta emot Sopetovs näringsanmälan är ett typiskt exempel på hur finländska tjänstemän i praktiken tillämpade passivt motstånd. Det var denna konkreta handling som igångsatte processen, men också i fallets fortsatta behandling agerade Lagercrantz och de andra magistratsledamöterna i enlighet med det passiva motståndets principer. Metoden hade sedan revolutionsåret I 848 använts på flera håll i Europa och var i Finland bekant från det konstitutionella blockets kamp mot förryskningen 1899-1905. Som idé utgick den från att tjänstemän skulle vägra lyda ryska lagar och påbud som var oförenliga med finsk grundlag, att de med alla till buds stående lagliga medel skulle motarbeta sådana lagars tillämpande, och slutligen, att de konsekvent skulle artikulera när och hur brott mot finsk lag begicks. ${ }^{23}$ Alla finländska tjänstemän slöt ingalunda upp bakom metoden. Huvudalternativet, den av gammalfinska partiet företrädda undfallenhetspolitiken, utgick från att det mest ändamålsenliga var att till varje pris behålla tjänsterna i finländska händer. Detta kunde förvisso

2I. Se t.ex. "Wiipurin maistraatin jäsenille kostetaan", Keski-Suomi I7/8 I9I2, s. 2; "'Yhdenvertaisuus'-laki käytännössä", Työ I7/8 I9I2, s. 2. Tidningarna hänvisar till uppgifter i rysk press.

22. "Likställighetslagens tillämpning", Dagens Tidning 23/8 I9I2, s. I; "Åtgärderna mot magistratsledamöterna i Viborg", Dagens Tidning 24/8 I9I2, s. I.

23. Steven Duncan Huxley, Constitutionalist Insurgency in Finland: Finnish "Passive Resistance" against Russification as a Case of Nonmilitary Struggle in the European Resistance Tradition, Studia historica 38, Helsinki: Suomen Historiallinen Seura I990, s. I-3, I66-I68. Undfallenhetslinjen försvagades kring I9ı2, till stor del på grund av konflikten kring likställighetslagen. Det tredje alternativet, det aktiva motståndet, var inte aktuellt I9I2. 
förutsätta en del eftergifter till den ryska regimen, men hindrade att tjänsterna hamnade i händerna på ryska tjänstemän som saknade kunskap om och förståelse för Finlands juridiska särställning. ${ }^{24}$

När Sereda och Popov den 22 augusti anlände till Viborg för att förhöra Lagercrantz, Palmroth och Fagerström befann sig ingen av de tre i staden, varför detektiver sändes ut till landsorten för att överlämna stämningsakten och kallelse till förhör. Fagerström och Palmroth anträffades de följande dagarna, men vägrade att infinna sig på den utsatta tiden. ${ }^{25}$ Palmroth fördes slutligen till förhör den 24 augusti, medan Fagerström med våld avhämtades mitt i magistratens sammanträde den 26 augusti. Båda vägrade att svara på frågor och framhöll att de som finländska tjänstemän endast accepterade att ställas till svaromål inför Viborgs hovrätt. Båda blev också häktade, men ställdes på fri fot efter att ha betalat en borgen på 500 rubel. $^{26}$ Flera poliser sändes också ut för att hitta Lagercrantz, som anträffades i tjänstegöromål på eftermiddagen den 24 augusti nära Oravankylä gästgiveri i S:t Andrea, 50 kilometer från Viborg. Inte heller han beaktade förhörskallelsen, och innan han anlände till Viborg hade Sereda och Popov hunnit återvända till S:t Petersburg. ${ }^{27}$

I Viborg började man nu spekulera huruvida Lagercrantz med våld skulle föras till S:t Petersburg för förhör, men Sereda och Popov återvände i början av september. Denna gång befann sig Lagercrantz i staden, men trots att de ryska domarna lät detektiver skugga honom nonchalerade han fortsatt förhörskallelsen. Den 4 september sändes polis till Lagercrantz bostad på Vasagatan. Lagercrantz uppmanade den kommissarie som fått i uppdrag att föra honom till förhör att läsa upp stämningsakten, varpå han meddelade att han inte hade någon som helst avsikt att "följa slika olagliga påbud". Han svarade också

24. Om undfallenhetspolitiken, se Pirkko Rommi, "Undfallenhetsriktningens ideologi", Päiviö Tommila (red.), Finlands ofärdsår I899-1917, Stockholm: Wahlström \& Widstrand, s. IOI-IO7.

25. "Likställighetslagens tillämpning", Dagens Tidning 23/8 I9г2, s. I; "Kanne Wiipurin maistraatin jäseniä wastaan 'yhdenvertaisuuslain"rikkomisesta", Karjala 23/8 I9I2, s. 2.

26. Om Palmroths förhör: "Likställighetslagens tillämpning i Viborg", Nya Pressen 24/8 I9I2, s. I; om Fagerströms förhör:"N.s. yhdenwertaisuuslain sowelluttaminen”, Turun Lebti 29/8 I9I2, s. I.

27. "Wiipurin maistraatin jäsenten ahdistaminen", Työmies 27/8 I9I2, s. 2. 
nekande när kommissarien frågade om han kunde använda telefonen, sannolikt för att rådgöra med sin chef. Eftersom Lagercrantz vägrade att samarbeta, återstod inget annat alternativ än att föra honom till länsstyrelsen med våld. Tolv polismän sändes till Vasagatan, och Lagercrantz som fortsatt vägrade följa med anklagade dessa för att låta sig utnyttjas som redskap för "laglösheter". Först när två konstaplar tog honom under armen konstaterade han att han "viker sig för våldet", men å det bestämdaste protesterar mot "dylikt groft öfvervåld". ${ }^{28}$ I sitt handlande följde Lagercrantz alltså det passiva motståndets principer, som gick ut på att lugnt och behärskat hänvisa till finsk lag och artikulera det rättsövergrepp som höll på att ske. Att göra fysiskt motvärn ingick däremot inte i det passiva motståndets idé. ${ }^{29}$

Lagercrantz fortsatte sitt passiva motstånd vid förhöret, där han $\mathrm{i}$ likhet med Palmgren och Fagerström konsekvent vägrade att svara på frågor. På några frågor svarade han spydigt, som när man efterfrågade hans namn: "Det bör ni väl känna till, eftersom ni låtit häkta mig". I övrigt framhöll han att han skulle träda i svaromål endast inför Viborgs hovrätt, om det förhöll sig så att han som finsk tjänsteman var anklagad för tjänstebrott. Efter två och en halv timmes resultatlöst förhör förklarade förhörsledarna Lagercrantz häktad, men de var beredda att ställa honom på fri fot mot en borgen på 500 rubel liksom de hade gjort med Fagerström och Palmroth. Redan före förhöret ryktades det dock i pressen att Lagercrantz skulle vägra betala borgen, vilket han också gjorde. Han gick därmed ett steg längre i sitt passiva motstånd än Fagerström och Palmroth, vilket resulterade i att han internerades i länsfängelset i Viborg. ${ }^{30}$ Dagen därpå inlämnades i Lagercrantz namn ett klagomål över olaga häktning till Viborgs hovrätt, som krävde en redogörelse över fallet av guvernör von Pfaler. Då hovrätten inte nöjde sig med förklaringen, där guvernören hänvisade till likställighetslagen, frigav hovrätten Lagercrantz och

28. "När olag tillämpas i Viborg", Wiborgs Nyheter 5/9 I9I2, s. 2; "Åtgärderna mot magistraten i Viborg", Hufoudstadsbladet 5/9 I9I2, s. 4. Lagercrantz handlade på samma sätt som Fagerström och Palmroth tidigare. Se Nuorvala, Krestyn miehet, s. I33-I37.

29. Huxley, Constitutionalist Insurgency, s. I68-170.

30. "När olag tillämpas i Viborg", Wiborgs Nyheter 5/9 I9I2, s. 2; "Åtgärderna mot magistraten i Viborg", Hufoudstadsbladet 5/9 I912, s. 4. 
anmälde von Pfaler för tjänstebrott till senatens justitiedepartement. Detta i sin tur resulterade i att Viborgs hovrätt åtalades för brott mot likställighetslagen. ${ }^{31}$

Lagercrantz hölls internerad i Viborg till den 27 september, varefter han förflyttades till rannsakningsfängelset Spalernaja i S:t Petersburg. ${ }^{32}$ Därifrån frigavs han genom försorg av sin ryska försvarsadvokat den I9 oktober, bara några dagar innan rättegången skulle inledas. Lagercrantz betonade i offentligheten att frigivningen inte hade skett på hans eget initiativ och att han personligen skulle ha föredragit att hållas häktad "tills rätten ansåg det vara sin plikt att fria honom". ${ }^{33}$

Vid rättegången i S:t Petersburg den 23 oktober försvarades Lagercrantz, Fagerström och Palmroth av P.N. Pereversev och V.D. Kusmin-Karavajev, två erkänt skickliga ryska advokater som stödde den finska saken. ${ }^{34}$ Från början var det inte alls givet att de åtalade skulle närvara vid rättegången. Deras personliga närvaro var enligt anklagelseakten inte obligatorisk, och enligt Kaarlo Nuorvala hade Lagercrantz under sin häktning meddelat att han inte ämnade ställa sig inför en olaglig domstol. ${ }^{35}$ Att inte infinna sig hade varit förenligt med det passiva motståndets idé och med de åtalades handlingssätt fram till rättegången. Det verkar ändå som om man tagit ett gemensamt beslut att personligen närvara i S:t Petersburg. Motivet var att man ville få maximal uppmärksamhet för Finlands sak och göra det konstitutionella tänkesättet känt både internationellt och i den ryska offentligheten, "dit liberala röster sällan nå". ${ }^{36}$

Rättegången fick stor uppmärksamhet och bevakades förutom av finsk och rysk press av många högt uppsatta jurister som följde med den på plats. Under rättegången tog sig de åtalades passiva motstånd fortsättningsvis uttryck i en konsekvent vägran att svara på frågor. Av

3I. Kannel, Viipurin hovioikeus, s. 7I-78. Fallet väckte särskilt stor bestörtning, eftersom det innebar att en högre rättsinstans blev dömd av en lägre.

32. "Kamreeri Lagercrantzin siirtäminen Pietarin wankilaan", Wiipuri 28/9 I9I2, s. 3; "Pietarin wankilaan siirtäminen", Wiipuri 29/9 I9ı2, s. 2. Lagercrantz hölls häktad i länsfängelset i Viborg mellan den 5/9 och den 27/9 och i rannsakningsfängelset i S:t Petersburg mellan den $27 / 9$ och den I9/ro.

33. "Kamrer Lagercrantz hemma igen", Wiborgs Nyheter 21/10 I9I2, s. 2.

34. "Den ryska rättegången mot Viborgs magistrat", Wiborgs Nyheter 23/10 I9I2, s. 2.

35. Nuorvala, Krestyn miehet, s. I48-150.

36. "Rättegången i dag", Wiborgs Nyheter 23/ıo I9I2, s. I. 
de inledande frågorna svarade de endast på den om sin ålder, medan de inte gav något svar på frågan om de kan ryska. När de själva gavs tillfälle att yttra sig utnyttjade de möjligheten till att än en gång argumentera för att de som finska medborgare, för ett brott som begåtts i Finland, endast kunde åtalas i en finsk domstol och i enlighet med finsk lag. Som Fagerström framhöll i sitt anförande saknade distriktsdomstolen i S:t Petersburg legitim rätt att åtala en finländsk tjänsteman som "svurit att åtlyda alla i Finland gällande lagar och författningar". ${ }^{37}$ Lagercrantz hänvisade i sitt eget slutanförande, förutom till att han hållits lagstridigt häktad i sju veckor, till samma legitimitetsprincip:

Jag har tidigare för rätten framhållit, att jag icke anser detta rättssammanträde lagligt och på den grund icke kommer att träda i svaromål. Då jag det oaktat infunnit mig till sammanträdet, har jag därmed endast velat yttermera framhålla det brott mot Finlands lagar, hela detta ärende innebär. ${ }^{38}$

Åklagaren, prokuratorsadjointen G.B. Nenorokomov, yrkade i sin slutplädering på det strängaste straff som föreskrevs för brott mot likställighetslagen på en tregradig skala som sträckte sig från böter till fängelse. Som en försvårande omständighet framhöll han de åtalades "sturskhet och hårdnackenhet", samt att de hade "dristat sig att förneka rättens auktoritet". Det stränga straffet motiverades ytterligare med att de åklagade enligt en "inbördes förut träffad öfverenskommelse uppenbarligen och afsiktligen hindrat tillämpningen av likställighetslagen". ${ }^{39}$ Lagercrantz, Fagerström och Palmroth dömdes till sex månaders fängelse, men däremot inte till förlust av sina ämbeten. Fram till dess att domen skulle offentliggöras, den 6 november I9ı2, släpptes de på fri fot. ${ }^{40}$ Domen överklagades därefter till apellationsdomstolen, som i sin dom i januari г9I3 höll fast vid distriktsdomstolens beslut. ${ }^{41}$ Slutligen

37. "Sex månaders fängelse", Dagens Tidning 24/ıo I9I2, s. I-3;"Åtgärderna mot Viborgs magistrat", Åbo Underrättelser 24/ı I9I2, s. 3.

38. "Åtgärderna mot Viborgs magistrat", Åbo Underrättelser 24/ıo I912, s. 3.

39. Domslut (avskrift), Rättegången mot tjänstemännen i Viborgs magistrat, 8, Leo Mechelins arkiv, Riksarkivet, Helsingfors.

40. "Rättegången mot medlemmarna av Viborgs magistrat", Borgåbladet 26/10 I9I2, s. 2; Leino-Kaukiainen \& Partanen, "Tiellä venäläiseen Suomeen”, s. 504.

4I. "Wiipurin maistraatin jutut", Wiipuri 4/7 I9I3, s. 2. 
satt Lagercrantz av fängelsestraffet först i början av år I9I4, efter att man med våld fört honom till Kresty-fängelset i S:t Petersburg. ${ }^{42}$

Rättegången mot Viborgs magistrat sågs i Finland allmänt som en skenrättegång. Det var uppenbart att den ryska regimen genom att döma Lagercrantz, Palmroth och Fagerström till fängelsestraff ville få till stånd ett prejudikat, som skulle avhålla andra finska tjänstemän från att följa deras exempel. ${ }^{43}$ Taktiken avskräckte ändå inte alla. Redan före rättegången hade magistraterna i flera städer vägrat att ta emot näringsanmälningar av ryska undersåtar, med samma motivering som man angett i Viborg. I offentligheten föll dock allt ljus hösten I9I2 på Lagercrantz, Palmroth och Fagerström, eftersom den ryska regimen inte ville sätta igång flera rättsprocesser innan det första fallet var slutbehandlat. ${ }^{44}$ Från år I9I2 och fram till Finlands självständighet dömdes femtio finländska tjänstemän för brott mot likställighetslagen, bland dem flera ledamöter av magistraterna i $\mathrm{Ny}$ stad, Tavastehus, Villmanstrand och Helsingfors. Åbo hovrätt följde det exempel Viborgs hovrätt statuerat, med följden att även dess ledamöter blev dömda för brott mot likställighetslagen. ${ }^{45}$ Ingen av dem som dömdes efter Lagercrantz, Palmroth och Fagerström närvarade personligen vid rättegången. Den sista finländaren som satt fängslad i Kresty för brott mot likställighetslagen friades först efter den ryska marsrevolutionen I9I7.

\section{DEN SAMTIDA OFFENTLIGHETEN}

Alla människor tala i dessa tider om fallet Lagercrantz, och alla säga med en mun, att den mannen är en riktig karlakarl. Just så ska en finne slåss. Det kännes riktigt godt i dessa bistra tider, att höra talas om mannamod och uppoffring för en idé och jag tror att denne vår Brutus har visat oss den väg på hvilken vi böra gå. ${ }^{46}$

\footnotetext{
42. "Våldsregimens offer", Wiborgs Nyheter I6/I I9I4, s. 2;"Hemma från Kresty", Wiborgs Nyheter I6/4 I9I4, s. 2.

43. "Taistelun mies", Karjala 2I/2 I928, s. 6.

44. Nuorvala, Krestyn miehet, s. 310-338.

45. Petra Hakala, "För lag och rätt - några finländska interner i Kresty I9I3-I9I5", Källan 2007:I, s. I3.

46. "Tragedin i Viborg", Tammerfors Nyheter 7/9 I9I2, s. 3.
} 
Som den första som frihetsberövades för brott mot likställighetslagen var Lagercrantz hösten I9I2 en av de mest omtalade personerna i Finland. Samtidigt som fallet upprörde, var maktbalansen till Rysslands fördel och finländarna stod rätt maktlösa inför händelserna. Det passiva motståndets idé omfattade ändå tanken om att en svagare part i en konflikt kan kämpa mot oförrätter genom att på bred front mobilisera motstånd mot övermakten. Genom att sprida information om oförrätterna och i form av hyllningar och offentliga åsiktsyttringar uttrycka kollektivt stöd för drabbade individer, försökte man demoralisera motståndaren och på så sätt försvåra att den förtryckande agendan genomdrevs. ${ }^{47} \mathrm{Att}$ den ryska regimen var förberedd på att den typen av åsiktsyttringar skulle förekomma, och att det i samband med dessa även kunde uppstå oroligheter, visar ett "hemligt cirkulär" som generalguvernör Seyn sände till guvernörerna i maj IgI2. I cirkuläret påminner han guvenörerna om att de ansvarade för ordningen i länet och för att polisen omedelbart skulle kväsa oroligheter. ${ }^{48}$

Så fort fallet med Viborgs magistrat blivit känt, konstaterade en insändarskribent i Dagens Tidning att en lavin hade satts i rullning, men att Lagercrantz, Fagerström och Palmroth i sin svåra belägenhet kunde räkna med stöd och "varm erkänsla av alla rätt tänkande medborgare" ${ }^{49}$ Som konkret bevis på denna sympati fick Lagercrantz, liksom andra drabbade tjänstemän före och efter honom, ta emot telegram, brev, kort och blomförsändelser. ${ }^{50}$ Sådana hälsningar sändes till familjen Lagercrantz redan efter häktningen, och flera strömmade in i samband med förflyttningen till S:t Petersburg och efter rättegången. I telegrammen, som ofta kollektivt representerade en viss ort, förening eller organisation, tackades Lagercrantz vanligtvis för sitt "exempelgivande uppträdande". ${ }^{51}$ Enligt en notis i tidningen Karjala gladde särskilt ett telegram familjen. Det var undertecknat med en pseudonym, av en person som tidigare hade varit anhängare av undfal-

47. Huxley, Constitutional Insurgency, s. I62-I68.

48. Generalguvernörens sekreta cirkulär till guvernörerna i maj ı9ı2, Generalguvernör Seyns handlingar, Hd: 3I, Generalguvernörskansliets arkiv, Riksarkivet, Helsingfors.

49. "Tillämpad olag", Dagens Tidning 2/8 I9I2, s. 3 .

50. Petra Hakala, "För lag och rätt - några finländska interner i Kresty I9I3-19I5", Källan 2007:I, s. I5.

5I. "Rättegången mot medlemmarna av Viborgs magistrat", Borgåbladet 26/ Io I9I2, s. 2. 
lenhetslinjen, men som nu intygade att ett enat Finland "från djupet av sitt hjärta" deltog i det lidande som det ryska övervåldet orsakat. ${ }^{52}$ Detta var ett tecken på att undfallenhetslinjen, traditionellt förfäktad av gammalfennomanerna, $\mathrm{i}$ den rådande situationen inte längre sågs som ett tillräckligt kraftigt vapen mot förryskningen.

De som hade möjlighet att följa med händelseförloppet på ort och ställe kunde visa sitt stöd genom att konkret stå vid de drabbades sida och uttrycka sin åsikt. Stadsborna i Viborg följde med händelserna allt sedan Sereda och Popov anlände till staden. Redan när Lagercrantz den 4 september fördes till förhör följde enligt tidningsrapporteringen en talrik publik med hur polisen hämtade honom i hans hem, förde honom till länsstyrelsens hus där han förhördes och därifrån vidare till länsfängelset. ${ }^{53}$ Allt efter som fallet fick mera uppmärksamhet ökade också det publika intresset. När Lagercrantz i slutet av september förflyttades till S:t Petersburg, ägde enligt Wiborgs Nyheter en "medborgerlig hyllning under hög stämning" rum på järnvägsstationen. En stor mängd stadsbor hade samlats för att önska den "lagtrogne och principfaste mannen ett vördsamt farväl och ett snart välkommen åter" och för att genom sin närvaro visa att Lagercrantz inte stod ensam i kampen mot olagligheterna:

Hvad komma skall, det skall manligen bäras, i hopp och tro att ljusare dagar gry. Motståndet skall fortsättas, och konsekvenserna skola vi manligt lida - såsom [Lagercrantz], hvilken med våldets makt [...] orättfärdigt bortsläpats från sitt fosterland. ${ }^{54}$

Nyheten om Lagercrantz förflyttning till S:t Petersburg spred sig blixtsnabbt längs järnvägen, och även på mellanstationerna - Perkjärvi, Nykyrka, Terijoki, Kellomäki, Kuokkala och Valkeasaari - möttes han av folksamlingar som hyllade honom med blommor, leverop och

52. "Myötätuntoisuuden osotuksia", Karjala I3/9 I9г2, s. 3.

53. "När olag tillämpas i Viborg", Wiborgs Nyheter 5/9 I9I2, s. 2.

54. "Kamrer Lagercrantz utrekvirerad från fängelset och förd till Ryssland", Wiborgs Nyheter 28/9 I9I2, s. 2. I Kellomäki, under färden till S:t Petersburg, överräcktes en adress med samma budskap: "Då ni nu lider för fäderneslandet, må medvetandet att tusende deltaga i edra lidanden vara eder en tröst." 
sång. ${ }^{55}$ Detta fick den Finlandskritiska tidningen Novoje Vremja att kritisera finländarnas "snedvridna fosterländskhet" som tagit sig uttryck i att man ännu vid S:t Petersburgs portar hyllade "passivisten" Lagercrantz - en person vars agenda gick ut på att förvägra ryssar fulla och likvärdiga rättigheter i sitt eget rike. ${ }^{56}$

Den största folksamlingen i samband med Lagercrantz-fallet uppstod efter hans frigivning från rannsakningsfängelset Spalernaja inför rättegången. Pressen rapporterar att to ooo stadsbor den 20 oktober hade samlats i kvarteren kring järnvägsstationen i Viborg för att välkomna honom hem. Hyllningarna tog sig uttryck i att Lagercrantz "på starka armar bars genom folkmassan under rungande lefverop", och därefter drogs till sitt hem på Vasagatan i en hästkärra. Tillfället urartade senare $\mathrm{i}$ tumult mellan polisen och folkhopen, från vilken det hördes regimkritiska rop som "ner med ordningsmakten, ner med Pekonen”, och några människor skadades. ${ }^{57}$ Efter incidenten försökte ordningsmakten stävja framtida oroligheter genom att förbjuda alla "hyllningar av demonstrativ art" i stadsrummet. ${ }^{58}$ Trots förbudet förekom liknande hyllningar, om än av allt att döma i något mindre omfattning, även när Lagercrantz återkom från rättegången, och när han I9I4 fördes till Kresty, respektive återkom efter avtjänat straff. ${ }^{59}$

Pressen spelade en viktig roll för att mobilisera det kollektiva motståndet mot förryskningen och för att uppmuntra de breda folklagren att protestera mot övergreppen. Detta mål försökte man uppnå bland annat genom att lyfta fram som förebilder de personer som fallit offer för den ryska regimens framfart. Lagercrantz passade väl in i martyrrollen, inte minst därför att han redan I9II hade råkat i konflikt med von Pfaler. Konflikten uppstod när Lagercrantz, då kronofogde

55. "Kamrer Lagercrantz utrekvirerad från fängelset och förd till Ryssland", Wiborgs Nyheter 28/9 I9I2, s. 2. På mellanstationerna hyllades Lagercrantz med patriotiska sånger som "Vårt land", "Karelarnas sång" och lantdagspsalmen. Sång hade sedan I80o-talet varit ett viktigt kollektivt uttryck för fosterländskhet. Se Matti Klinge, Från lojalism till rysshat, [Helsingfors]: Söderströms förlag I988, s. I20-I40.

56. "Nowoje Wremjan' Suomen sähkösanomat", Karjala I3/9 I9I2, s. 3.

57. "Kamrer Lagercrantz hemma igen", Wiborgs Nyheter 2I/IO I9I2, s. 2.

58. Nuorvala, Krestyn miehet, s. 157-I59.

59. "Rättegången mot medlemmarna av Viborgs magistrat", Borgåbladet 26/ı I9I2, s. 2; "Wiipurin maistraatin yhdenvertaisuuslakijutut", Wiipuri I7/I I9I4, s. 2; "Vapaiksi Krestystä", Wiipuri I7/4 I9I4, s. 2. 
i Stranda härad, efter von Pfalers tillträde dröjde med det besök som länets tjänstemän förväntades avlägga hos en nyutnämnd guvernör. Lagercrantz fick senare order om att infinna sig hos von Pfaler som tog emot honom med "starka ord av missnöje över dröjsmålet". Att Lagercrantz dessutom var klädd i kostym - inte i frack som kutymen föreskrev - tolkade von Pfaler i ljuset av dröjsmålet som ett tecken på bristande respekt och som ett hinder för ett framtida samarbete. ${ }^{60}$

Trots att Lagercrantz senare avlade ett nytt besök iklädd frack lät sig von Pfaler inte blidkas utan yrkade i en hemställan till senaten på att Lagercrantz skulle bestraffas för motstånd mot överordnad. Senaten krävde en redogörelse av Lagercrantz, som svarade att dröjsmålet förklarades av tjänsteåligganden och sjukdom. Detta bestyrkte han med läkarintyg och intyg av en skräddare över att hans kostym var ny och snygg. Senaten förespråkade tillfälligt avskedande, men då von Pfaler insisterade på att Lagercrantz idkat "medveten provokation" godkände den på framställning av generalguvernör Seyn i januari I9ı2 permanent avskedande. ${ }^{61}$ Avskedandet väckte upprörda känslor och stärkte finländarnas farhågor inför framtiden."Stormcentrum närmar sig alltmer", rubricerade Wiborgs Nyheter sin artikel om incidenten. ${ }^{62}$ Det godtyckliga avskedandet av en erfaren tjänsteman, som både överordnade och allmänheten kände som plikttrogen, noggrann och human, tolkades som ytterligare ett steg i riktning mot den ryska regimens mål att bereda rum för tjänstemän som kunde driva igenom dess förryskningsprogram. ${ }^{63}$ Redan tidigare hade rensningar skett $\mathrm{i}$ de centrala ämbetsverken, bland länsguvernörerna och i polismakten, men med Lagercrantz avskedande nådde rensningarna den lokala administrationen. ${ }^{64}$

6o. "En ny frack-guvernör", Hufvudstadsbladet 27/I I9I2, s. 4. von Pfaler tillträdde den ıo februari I9II. Om avskedandet se även Koskivirta,"Venäläistäminen", s. I66-ı67.

61. "Kruununvouti B Lagercrantz erotetaan virasta", Wiipuri 27/I I9I2, s. 5; "Kruununvouti B. Lagercrantzin erottaminen”, Wiipuri 30/1 I912, s. 3.

62. "Transkaspiska metoder", Wiborgs Nyheter 27/I I9I2, s. 2; "Kronofogden Lagercrantz afsked", Wiborgs Nyheter 8/2 I9I2, s. 2.

63. "Senaatin päätös kamreeri Lagercrantzin asiassa", Karjala 27/I I9I2, s. 2; "Rannan kihlakunnan kruununwouti Brutus Lagercrantz erotettu", Wiipurin Sanomat 29/I I9I2, s. 2.

64. Pertti Luntinen, F. A. Seyn I862-I9I8. A Political Biography of a Tsarist Imperialist as Administrator of Finland, Studia Historica I9, Helsinki: Suomen Historiallinen Seura I985, s. I38-I40; Koskivirta, "Venäläistäminen”, s. I49-I6I. 
Redan i början av I9I2 var Lagercrantz alltså iklädd rollen som ett passivt "offer" för den ryska regimens godtycke och "oerhörda brutalitet". ${ }^{65}$ Som ett offer beskrevs han även i samband med konflikten kring likställighetslagen, men betoningarna försköts så till vida att tidningarna nu framhöll det medvetna och aktiva i hans handlande. Beslutet att inte ta emot Sopetovs näringsanmälan beskrevs, med alla de risker det medförde, som på förhand överenskommet, vilket det av allt att döma också var. Erkki Paavolainen och Anu Koskivirta visar att de konstitutionellt sinnade, i närvaro av bland andra Pehr Evind Svinhufvud, Tekla Hultin och Werner Fagerström, redan innan likställighetslagen trädde i kraft ordnade ett flertal möten i Viborg där man gemensamt kom överens om hur man skulle handla den dagen lagen för första gången prövades. ${ }^{66}$ Magistratens ledamöter fattade alltså sitt beslut väl medvetna om de möjliga konsekvenserna, men de hade inget alternativ: "Ställda i valet mellan att handla i enlighet med sin tjänstemannaed och sin plikt såsom finska medborgare eller att följa ett lagstridigt påbud ha medlemmarne i Viborgs magistrat icke kunnat tveka." 67

Genom att man betonar det aktiva handlandet framom det passiva martyrskapet kan ett offer förvandlas till hjälte. En individ som är beredd att offra sin personliga välgång för att försvara det som ur den kollektiva nationens synvinkel är det rätta, i det här fallet finsk lag, passar väl in i rollen som förebild för hur nationens övriga medlemmar idealt bör handla i en motsvarande situation. ${ }^{68} \mathrm{I}$ enlighet med denna logik framställde pressen Lagercrantz, i egenskap av likställighetslagens första offer, som ett"föredöme i laglydnad"69 och som en modig och karaktärsfast individ som offrade sin personliga välfärd för ett högre ändamål. I praktiken gjorde han detta genom att oavbrutet

65. "Fallet Lagercrantz", Wiborgs Nyheter 8/2 I9I2, s. 2. Se även "Wirkavallan uhri", Rauman Lebti 30/I I9I2, s. I.

66. Paavolainen, Sanomalehti Karjalan kohtaloita, s. I75-176; Koskivirta, "Venäläistäminen", s. r69.

67. "Den ryska likställighetslagen och Viborgs magistrat", Nya Pressen I/8 I9ı2, s. I.

68. Johanna Wassholm,"Att skapa och reproducera minnet av en nationell storman. A. I. Arwidsson (I79I-I858) i storfurstendömet Finlands historiekultur på I80otalet", Scandia: Tidskrift for historisk forskning 83, 20I7:I, s. 51-52.

69. "Rättegången mot medlemmarna av Viborgs magistrat", Borgåbladet 26/ Io I9I2, s. 2. 
protestera mot och ifrågasätta legitimiteten hos en rysk regim som "kränker rättsprinciper, hållna i helgd i alla kulturländer" och som uppmanar medborgare och tjänstemän till "omoraliska handlingar sådana som rättsbrott". ${ }^{70}$

De förebildliga dragen i Lagercrantz karaktär framhävdes ytterligare genom att de kontrasterades mot den föreställda motståndarens negativa egenskaper. På en principiell nivå representerades motståndet av den ryska regimen med sin Finlandsfientliga agenda, men på det praktiska planet personifierades det i första hand av de finländare som förverkligade agendan. Som Lagercrantz främsta antagonist framställdes von Pfaler, som pressen redan i samband med frackepisoden hade beskrivit som en rysk "hejduk". ${ }^{71}$ Guvernören anklagades för att själv ha provocerat fram incidenten och förlöjligades för att ta kritik personligt. Hans tendens att "se kränkningar över allt" tolkades som ett tecken på att han hade dåligt samvete över sitt eget rättskränkande handlande. ${ }^{72}$ Till skillnad från Lagercrantz, som representerade "bepröfvad, rakryggad tjänstemannaduglighet", karakteriserades von Pfaler, i likhet med den förryskade senaten, av ett "vaket sinne för lismeriet och lycksökeriet" och "lakejsinne mot de maktägande men brutalitet mot underlydande". ${ }^{73}$

Wiborgs Nyheter anklagade guvernören under rubriken "Transkaspiska metoder", en anspelning på von Pfalers tidigare tjänstgöring i Centralasien, för att tillämpa sitt ryska "tschinovniksinne" på finländska förhållanden. Ryskans tjinovnik betyder ämbetsman, men har som lånord $\mathrm{i}$ främmande språk vanligtvis använts som en sarkastisk beteckning på en tjänsteman som uppvisar överdriven byråkratisk nit eller som är påverkad av en godtycklig rysk förvaltningskultur. ${ }^{74}$

70. "Den ryska likställighetslagen tillämpas", Nya Pressen I/8 I9ı2, s. I.

71. "Transkaspiska metoder", Wiborgs Nyheter 27/I I9I2, s. 2; "Rannan kihlakunnan kruununwouti Brutus Lagercrantz erotettu", Karjala 27/I I9I2, s. 2.

72. "En ny frack-guvernör", Hufvudstadsbladet 27/r I9I2, s. 4. En skämtteckning av mötet mellan von Pfaler och den kostymklädde Lagercrantz förekom på pärmen av satirtidskriften Tuulispää (I912:5). Se även Wassholm, "Brutus Lagercrantz", s. 205 .

73. "Transkaspiska metoder", Wiborgs Nyheter 27/I I9I2, s. 2.

74. Se Nordisk Familjebok. Uggleupplagan 29. Tidsekvation-Trompe, Stockholm: Nordisk familjeboks förlags Ab I9I9, http://runeberg.org/nfci/or2o.html (hämtad 26/8 2020). 
Som guvernör hade von Pfaler förvisso rätt att kräva ordning och disciplin, men erfarna och lagtrogna finländska tjänstemän som Lagercrantz hade varken "lust eller möjlighet att ikläda sig en lakejs skepnad med bugningar och smilande tal”. En västerländskt sinnad finländsk tjänsteman skulle aldrig visa prov på "kryperi, servilism och tallriksslickeri" som en guvernör i Ryssland kanhända kunde förvänta sig av sina underordnade. ${ }^{75}$ Detta motsatsförhållande avspeglar en lång idéhistorisk tradition i Europa, där en "västerländsk anda" som representerar rättsstaten ställs mot en "österländsk" som representerar barbari och godtycke. ${ }^{76}$

\section{Minnet AV EN PASSIV MOTSTÅNDSMAN}

Det var en tid när Brutus Lagercrantz namn var känt överallt i vårt land och då bäraren av detta namn av alla rättsinnade medborgare omfattades med de varmaste sympatier. Han var nämligen ej allenast den förste av våra lagtrogna tjänstemän, som för sin trohet mot landets lagar drabbades av den ryska våldsregimens framfart, utan detta skedde upprepade gånger. ${ }^{77}$

När Brutus Lagercrantz avled den r juni I929, sjutton år efter händelserna i Viborg, blev han fortfarande ihågkommen för sin kamp mot likställighetslagen. I liknande ordvändningar hade han hyllats redan i samband med sin 70-årsdag två år tidigare, då han nu liksom under sin livstid lyftes fram som det första "offret för den famösa s.k. likställighetslagen" och som "en principernas man och orubbligt lagtrogen". ${ }^{78}$ Hans självuppoffrande karaktär betonades och han tackades "för sitt stora uppoffrande arbete" för fosterlandet. Han presenterades därtill som en av de tjänstemän som före Finlands självständighet "hellre gingo i ryska fängelser” än svek finsk lag - något som var värt att

75. "Transkaspiska metoder", Wiborgs Nyheter 27/I I9I2, s. 2.

76. Se t.ex. Iver B. Neumann, Uses of the Other. The "East" in European Identity Formation, Minneapolis (Minn.): University of Minnesota Press 1999.

77. "Fältkamrer Brutus Lagercrantz död", Hufvudstadsbladet 4/6 I929 (uppl. B), s. 3 . Se även "Brutus Lagercrantz", Wiborgs Nyheter 3/6 I929, s. I.

78. "Fältkamrer Brutus Lagercrantz 70 år", Wiborgs Nyheter I3/5 I927, s. 2. Se även "Sjuttio år", Hufoudstadsbladet I2/5 1927, s. 6. 
"äras och aktas" av varje fosterländskt sinnad finländare som värnade om lag och rätt. ${ }^{79}$

Eftervärlden tillskriver alltså Lagercrantz i stor utsträckning samma karaktärsdrag som hans samtid, men placerar samtidigt in kampen kring likställighetslagen i den förändrade geopolitiska situation som Finland befann sig i efter I9I7. I den unga självständiga republiken tillskrevs det förflutna nya betydelser, då historiska händelser anpassades till ett nytt samhällsklimat och en ny nationell agenda. Efter de svåra årtiondena i slutet av den ryska tiden och ett splittrande inbördeskrig I9I8 fanns det ett stort behov att framhålla nationens enhet. Detta mål kunde man uppnå genom att framhålla ett kollektivt motstånd mot en gemensam rysk fiende. ${ }^{80}$ Bilden av Finland som försvarare av västerländsk rättsordning gentemot ryskt godtycke eller"österländskt barbari” artikulerades nu om möjligt ännu tydligare. ${ }^{81}$

Minnet av händelserna ı9ı2 hölls vid liv i det självständiga Finland tack vare Edvin Wiréns bok Från S:t Petersburgs fängelser som publicerades I9I7, i den brytpunkt då Finland höll på att lösgöra sig från Ryssland. Boken handlar framför allt om de dömda finländska tjänstemännens liv i ryska fängelser, men beskriver samtidigt med hjälp av livfulla metaforer den fara som hotat Finland r9I2. I introduktionen beskriver Wirén hur "[m] örka, för Finland hotande moln" åter hade börjat samlas på himlen som i några år varit "klar och fri" - ett Finland där folket fătt leva i "ostörd frid under hägnet av landets egna okränkta lagar”. De högtidliga löften som Alexander I givit vid Borgå lantdag I809, och som för finländarna hade gällt som "fasta och oryggliga", bröts åter en gång kring I9Io när den ryska regimen med list och "fräcka våldshandlingar" försökte införa "laglöshet, godtycke och anarki" i ett "fredligt kulturland". Likställighetslagen var ett led i det "förstörelsearbete" som syftade till att eliminera Finlands

79. "Dödsfall”, Wasa-Posten 4/6 I929, s. 2;"Fältkamrer Brutus Lagercrantz död", Hufvudstadsbladet 4/6 1929 (uppl. B), s. 3 .

8o. Se t.ex.Johanna Wassholm, "Storslagen seger eller ärofullt nederlag? Slaget vid Rilax i svensk, rysk och finsk historiekultur", Nils Erik Villstrand \& Kasper Westerlund (red.), Stor seger - litet nederlag? Perspektiv på sjöslaget vid Rilax I7I4, Meddelanden från Sjöhistoriska institutet vid Åbo Akademi 34, Åbo: Sjöhistoriska institutet 2015, s. I47.

8I. Se t.ex. "Tsareenit toivorikkaita", Pohjan Voima 9/4 I926, s. 2; "Taistelun mies", Karjala 2I/2 I928, s. 6. 
autonomi - en "upprörande rättskränkning” och en "vrångbild av allt vad lagstiftning heter". Från den dag lagen trädde i kraft hade ett "damoklessvärd" vilat över Finlands myndigheter och tjänstemän. ${ }^{82}$

Det är i denna hotfulla situation som Lagercrantz i pressen på r920-talet lyftes fram som den första av de modiga tjänstemän som var beredda att offra sin egen välgång "av trohet mot landets konstitution". ${ }^{83}$ Striden I9I2 hade inte utkämpats med eld och svärd, utan med lag, och Finlands folk hade orsak att vara tacksamt över att rätt personer då hade befunnit sig på rätt plats. I flera olika sammanhang slog eftervärlden med facit i hand fast att lag och rätt hade segrat, och att de självuppoffrande tjänstemän som motsatt sig likställighetslagen hade bestått den prövning som den ryska regimen hade ställt dem inför. ${ }^{84}$ I en artikel i Hufoudstadsbladet i januari 1923 med anledning av tioårsminnet av Viborgs hovrätts fängslande I9I3 uttrycks denna tanke med följande ord:

För högt kan det ej skattas att motståndet blev så kraftigt, som fallet var och att det första hugget träffade män, som ej tvekade att göra vilka uppoffringar som helst då det gällde värnandet av fosterlandets lagbundna samhällsskick. ${ }^{85}$

Skildringarna av händelserna I9ı2 belyser hur de finsk-ryska relationerna före I9I7 framställdes i finländsk offentlighet på 1920- och I930-talen. Det var typiskt att man betonade konflikt framom samverkan och att man framhävde Karelen som en förpost, där de finskryska motsättningarna hade varit särskilt starka. ${ }^{86}$ Att kampen kring likställigheten hade börjat just i Viborg, som alltid hade fått ta de första stötarna när "ofärd från öster ryckt in i landet", var något som

82. Wirén, Från S:t Petersburgs fängelser, s. 6-8.

83. "Taistelun mies", Karjala 2I/2 I928, s. 6; "Hautaus", Helsingin Sanomat 15/6 I929, s. 3 .

84. Wirén, Från S:t Petersburgs fängelser, s. 8, 15.

85. "Ett tioårsminne i kampen för landets lag och rätt", Hufoudstadsbladet 28/I I923, s. 8.

86. Aleksi Mainio \& Anu Koskivirta, "Viipurin poliittiset jännitteet - tapahtumia ja historiografiaa", Anu Koskivirta \& Aleksi Mainio (toim.), Politiikan ja jännitteiden Viipuri 1880-1939, VSKS:n Toimitteita 2I, Helsinki: Viipurin Suomalainen Kirjallisuusseura 20I9, s. 7; Koskivirta, "Venäläistäminen", s. I43. 
även Wirén framhöll som följdriktigt. Ett annat karakteristiskt drag var att det konstitutionella motståndet inkorporerades som ett centralt element i berättelsen om Finlands väg till självständighet. Behovet av att uppvisa en enad front gentemot Sovjetunionen gjorde att man ända fram till i980-talet tenderade att framställa det passiva motståndet i slutet av storfurstendömets tid som överdrivet hegemoniskt. ${ }^{87}$ I verkligheten hade både de politiska partierna och tjänstemannakåren i slutet av ryska tiden varit starkt splittrade $\mathrm{i}$ fråga om den mest effektiva metoden att motverka de ryska likriktningsåtgärderna.

Mellankrigstidens hegemoniska berättelse om det passiva motståndets betydelse är ett utmärkt exempel på hur det förflutna anpassas till behov i samtiden och på hur det är "vinnaren som skriver historien". Självständighetstidens första historiska översiktsverk och läroböcker avspeglade den konstitutionella linjens historiesyn, där självständigheten tolkades som en återgång till det svenska rättsarvet, medan den ryska tiden började framställas som en parentes. ${ }^{88}$ Där eftervärlden inkorporerade de passiva motståndsmännen i berättelsen om Finlands väg till självständighet, framstod undfallenhetsmännen i backspegeln betraktade som förlorare. I en tid då man betonade motsättningar gentemot det ryska låg det nära till hands att framställa tjänstemän som gett efter för rysk lag som naiva och godtrogna, till den grad att undfallenheten kunde jämställas med landsförräderi. När man 1923 uppmärksammade ıo-årsminnet av händelserna, som fått sin början med häktningen av Lagercrantz, framhöll pressen att konflikten kring likställighetslagen I9I2 var ett "gemensamt minne av skam för den ryska förtrycksregimen och gammalfennomanin". ${ }^{89}$

Som individ intog Lagercrantz ingen central plats i mellankrigstidens minne av kampen mot förryskningen. I den mån händelserna uppmärksammades var det kollektivets passiva motstånd som lyftes fram, exempelvis i den av Skyddskåren utgivna tidskriften Hakkapeliit-

87. Marko Tikka \& Jari Eilola, "Lakien synty ja oikeudenkäytön ihanteet", Petri Karonen \& Antti Räihä (toim.), Kansallisten instituutioiden muotoutuminen. Suomalainen historiakuva Oma Maa-kirjasarjassa I9oo-1960, Historiallisia Tutkimuksia 267, Helsinki: Suomalaisen Kirjallisuuden Seura 20I4, s. I88-ı9o.

88. Päiviö Tommila, Suomen historiankirjoitus. Tutkimuksen historia, Porvoo-Helsinki - Juva: Werner Söderström Osakeyhtiö I989, s. I94.

89. "Eräs wenäläisen sortowallan ja suomettarelaisuuden yhteinen häpeämuisto", Suomen Sosialidemokraatti 24/9 1923, s. I. 
ta som I932 publicerade en artikel om händelserna I9I2 under rubriken "Likställighetslagens martyrer". ${ }^{90}$ Som ett slags litterärt monument över offren för likställighetslagen kan man betrakta Kaarlo Nuorvalas verk Krestyn miehet, som publicerades i939. Inför vinterkrigets utbrott var det lätt att hitta paralleller till den hotfulla situation Finland befunnit sig i I9I2, och här kunde Kresty-männen stå som förebilder för hur varje rätt tänkande finländare borde handla i den aktuella situationen.

Efter andra världskriget föll händelserna i Viborg I9ı2 i hög grad i glömska både i historieskrivningen och i offentligheten, vilket är förenligt med den efterkrigstida historieskrivningens tendens att osynliggöra finsk-ryska konflikter i det förflutna. Ett av få undantag är en artikel i tidningen Maaseudun Tulevaisuus på självständighetsdagen I962, där man lyfter fram 5o-årsminnet av kampen kring likställighetslagen. I artikeln framställs händelserna I9I2 som en "motståndskamp som förebådade självständigheten", medan Lagercrantz och de andra Kresty-männen beskrivs som "den vapenfria frihetskampens hjältar". ${ }^{91}$

\section{Slutsatser}

I den här artikeln har jag med utgångspunkt i en enskild tjänsteman, Brutus Lagercrantz, studerat hur det finländska passiva motståndet tog sig uttryck i den konflikt mellan rysk och finsk rättsuppfattning som likställighetslagen I9I2 gav upphov till. Syftet har varit att redogöra för bakgrunden till konflikten och för hur det passiva motståndets principer i praktiken tog sig uttryck i Lagercrantz handlande och i det omgivande samhällets och pressens förhållningssätt till honom. Därtill har jag intresserat mig för hur händelserna och Lagercrantz har skildrats av eftervärlden. Genom att studera det passiva motståndets praktiker vill jag komplettera bilden av hur metoden tillämpades på gräsrotsnivå och av de konsekvenser detta kunde få för en enskild tjänsteman.

Lagercrantz och andra konstitutionellt sinnade finländska tjänstemän tillämpade det passiva motståndet genom att konsekvent vägra att lyda ryska lagar och påbud som stred mot finsk lag och rättsupp-

90. "Yhdenvertaisuuslain marttyyrit", Hakkapeliitta I932:3, s. 70-72.

91. "Krestyn vangit", Maaseudun Tulevaisuus 6/I2 I962, s. II-I2. 
fattning. I praktiken innebar detta att man vägrade att infinna sig till förhör, att svara på frågor och att erkänna ryska domstolars rätt att döma finska tjänstemän för tjänstebrott. Samtidigt artikulerade man de rättskränkningar mot finsk lag som den ryska regimen begick. Det passiva motståndet synliggjordes inte enbart i de enskilda tjänstemännens ord och handlingar, utan även i omgivningens förhållningssätt till dem. Eftersom finländarna hade få möjligheter att påverka situationen med maktmedel försökte man i stället påverka genom att uttrycka sitt stöd för de drabbade, exempelvis genom hyllningar på offentliga platser och telegram, kort och blomsterhyllningar. Syftet med dessa handlingar var dels att manifestera att de drabbade inte stod ensamma i sin kamp, dels att demoralisera de personer som tilllämpade de ryska lagarna.

I egenskap av likställighetslagens första "offer" var Brutus Lagercrantz under några månaders tid I9I2 en av de mest omtalade personerna i finländsk offentlighet. Som analysen visat var han också i någon mån ihågkommen under mellankrigstiden. Den roll som han spelat I9I2 platsade väl i mellankrigstidens hegemoniska nationella berättelse, där modiga och självuppoffrande individer ansågs ha spelat en avgörande roll i kampen mot den ryska likriktningspolitiken, och därmed för Finlands väg mot självständighet. Efter kriget, då ett förändrat förhållande till Sovjetunionen ledde till att man i Finland tenderade att osynliggöra rysk-finska konflikter i det förflutna, fick däremot Lagercrantz och kampen mot likställighetslagen en mera undanskymd roll. Trots att Lagercrantz när rättskampen var som hetast I9I2 gjordes till ett ideal för hur en finländsk tjänsteman borde handla när den finska nationen var hotad, bleknade minnet av honom så småningom. 